\title{
GERAK POLITIK UANG PADA PILKADA DUMAI 2020: SARANA PENDIDIKAN POLITIK YANG BAIK BAGI MAHASISWA DI PERGURUAN TINGGI SE-KOTA DUMAI
}

\author{
Lis Hafrida \\ STIE Tuah Negeri, Indonesia \\ lis.hafrida@gmail.com
}

\begin{abstract}
This research was a qualitative descriptive study, aimed at describing the application of political education received by students on campus to money politics that occurred in the Election of Mayor and Deputy Mayor at Dumai in 2020. The instrument used a questionnaire developing Guttman scale. Its population was all students who are enrolled in universities throughout Dumai. Respondents amounted to 760 people who were selected by incidental sampling technique. Some findings of this study were: (1) A total of $74.7 \%$ of students in the city of Dumai knew about money politics; (2) $71.7 \%$ of respondents knww the purpose of money politics; (3) 79.9\% of respondents had experience of receiving money from the success team and/or pairs of candidates; (4) A total of 78.9\% of student respondents already knew the impact of money politics on the 2020 Dumai Mayor and Deputy Mayor Election; (5) A total of $73.6 \%$ of respondents had experience receiving money from unscrupulous pairs of candidates during the previous election when the previous election was held; (5) Questions regarding the prediction of money politics during the election was $85 \%$ of respondents answered that it would not happen; (6) The statement of the respondent's attitude when receiving money and choosing the candidate pair in question would be made by $22.1 \%$ of the respondents; and (7) A total of 71.4\% of respondents did not accept the money given and did not choose the candidate pair. In conclusion, from the percentage of the data above, realization of political education received by the students in some campus in Dumai with the attitude towards the rejection of money politics in happened in Dumai on 2020 Mayor election is better.
\end{abstract}

Keywords: Money Politics; Political Education; Dumai's Mayor and Deputy Mayor Election in 2020

\begin{abstract}
Abstrak
Penelitian ini merupakan penelitian deskriptif kualitatif, bertujuan untuk mendeskripsikan penerapan pendidikan politik yang diterima mahasiswa di kampus terhadap politik uang yang terjadi dalam Pemilihan Walikota dan Wakil Walikota Dumai tahun 2020. Instrumen penelitian ini adalah angket menggunakan skala Guttman. Populasi penelitian adalah seluruh mahasiswa yang terdaftar di perguruan tinggi se-kota Dumai. Responden berjumlah 760 orang yang dipilih dengan teknik sampling insidental. Temuan penelitian ini adalah: (1) Sejumlah 74,7\% mahasiswa di kota Dumai mengetahui tentang apa itu politik uang dan 25,3\% tidak mengetahuinya; (2) Sebesar 71,7\% responden mengetahui tujuan dari politik uang; (3) 79,9\% responden memiliki pengalaman menerima uang dari tim sukses dan atau pasangan calon peserta pemilihan; (4) Sejumlah78,9\% responden sudah mengetahui dampak politik uang terhadap Pemilihan Walikota dan Wakil Walikota Dumai 2020;(5) Sebanyak 73,6\% responden memiliki pengalaman menerima uang dari pasangan calon pada pemilu sebelumnya; (5) Pertanyaan tentang prediksi akan adanya politik uang saat Pemilihan
\end{abstract}


Walikota dan Wakil Walikota tahun 2020 dijawab dengan $85 \%$ responden menjawab tidak akan terjadi; (6) Pernyataan sikap responden saat menerima uang dan memilih pasangan calon yang dimaksud dilakukan oleh $22,1 \%$ responden; dan (7) Sejumlah 71,4\% responden bersikap tidak menerima uang yang diberikan dan tidak memilih pasangan calon tersebut. Jadi penerapan pendidikan politik yang diterima mahasiswa di kampus dengan sikap terhadap penolakan politik uang dalam pemilu Walikota Dumai 2020 sudah baik.

\section{Kata Kunci: Politik Uang; Pendidikan Politik; Pilkada Dumai 2020}

\section{Pendahuluan}

Pemilu atau singkatan dari Pemilihan Umum merupakan pergelaran akbar demokrasi politik bagi rakyat Indonesia dan para pasangan calon yang digelar setiap lima tahun sekali. Pesta demokrasi ini merupakan wujud kedaulatan rakyat dan bertujuan untuk memilih perwakilan rakyat yang duduk di kursi DPR (Dewan Perwakilan Rakyat), DPD (Dewan Perwakilan Daerah), DPRD (Dewan Perwakilan Rakyat Daerah) dan Presiden dan Wakil Presiden dan terdiri dari para kandidat yang mewakili partai-partai yang ada.

Para kandidat yang mencalonkan diri sebagai calon legislatif (caleg) saling berkompetisi untuk mendapatkan dukungan berupa pemberian suara dari masyarakat. Berbagai usaha pun dilakukan oleh para caleg ini agar masyarakat bersimpati dan bersedia memberikan suaranya untuk mau memilihnya. Contoh cara yang dinilai taat asas seperti : (1) Para caleg ini memperkenalkan visi dan misi serta program jangka panjang yang dimilikinya kepada masyarakat selaku pemilih, dan (2) Caleg memberikan track record (rekam jejak) yang baik kepada masyarakat. Lebih lanjut, dikarenakan media massa berkewajiban untuk menyampaikan informasi dalam bentuk siaran yang cermat, jujur dan berintegritas maka informasi politik berupa kampanye visi dan misi serta track record para caleg ini melalui media massa pun dilibatkan sepenuhnya. Media massa berupa media cetak dan online ini dinilai sebagai sarana yang efektif untuk menyebarkan informasi politik kepada masyarakat luas yang terdiri dari beragam etnis dan agama (Firdaus, 2020).

Secara tegas pelaksanaan pemilu yang jujur dan adil dan terbebas dari politik uang di Indonesia menurut Firdaus (2020) telah diatur dalam Undang-Undang Nomor 32 Tahun 2008 tentang Pemberhentian Kepala Daerah dan Undang-Undang Nomor 8 Tahun 2012 tentang Pemilihan Umum Anggota Dewan Perwakilan Rakyat, Dewan Perwakilan Daerah, dan Dewan Perwakilan Rakyat Daerah serta Peraturan KPU Nomor 15 Tahun 2013 tentang Pedoman Pelaksanaan Kampanye. Hukuman yang tegas bila ditemukan adanya tindakan money politics dalam pemilu juga telah diatur dalam UU nomor 8 Tahun 2012 tersebut pasal 301 ayat 1. Dalam pasal ini dijelaskan bahwa hukuman pidana diberlakukan tidak hanya bagi calon legislatif yang terlibat politik uang saja tetapi juga pengurus partai politik, juru kampanye, personal dan organisasi yang ditunjuk sebagai peserta pemilu.

Tetapi beberapa oknum caleg ditemukan oleh aparat penegak hukum dan petugas penyelenggara pemilu melakukan pelanggaran politik uang ini. Tujuannya adalah untuk membeli suara masyarakat melalui pemberian sejumlah uang atau barang kepada masyarakat tersebut dan disayangkan sekali kegiatan ini dilakukan dalam keadaan sadar (Robi Cahyadi Kurniawan, 2019). Hal ini jelas-jelas telah menjadi fenomena buruk dan mencederai demokrasi di Indonesia karena meredupkan prinsip jujur dan adil dalam pemilu.

Politik uang ini dikelompokkan dalam tindakan pelanggaran pemilu dan termasuk dalam kelompok pidana pemilu. Hal ini tidak dapat dipungkiri karena pemilihan umum memerlukan modal (uang) baik oleh penyelenggara maupun peserta pemilu itu sendiri, dalam hal ini para caleg. Contoh sederhana saja pada saat kampanye pemilihan presiden dan wakil presiden atau kepala daerah seperti Walikota dan wakil walikota. Kampanye ini bersifat terbuka dan menghadirkan massa (masyarakat) dalam jumlah besar. Untuk mencapai ke tempat 
berlangsungnya kampanye maka massa tadi dibekali sejumlah uang dan atribut. Dalam sudut pandang hukum, hal ini sudah termasuk ke dalam politik uang.

Pendidikan politik merupakan aspek penting untuk menciptakan karakter unggul untuk menghadapi tantangan di era globalisasi saat ini. Karakter unggul yang dimaksud antara lain ditinjau dari segi potensi dalam diri individu seperti bakat, keahlian, pengetahuan dan kepemimpinan, serta intelektual dalam lingkungan akademik. Perguruan tinggi atau kampus menjadi salah satu wadah bagi mahasiswa untuk menemukan jati diri dan mengimplemetasikan berbagai hasil pemikiran mereka. Oleh karena itu pendidikan politik menjadi poin penting dalam menciptakan mahasiswa yang sadar akan hak dan kewajibannya sebagai warga negara. Tolak ukur keberhasilan pendidikan politik ini diantaranya terciptanya wagra negara yang berkualitas di tengah masyarakat.

Dalam kaitannya dengan dunia kampus, kampus merupakan salah satu tempat yang memfasilitasi adanya pendidikan politik yang bersifat preventif. Menurut Almond dalam (Tri Wulandari \& Dayati, 2020) pendidikan politik ini adalah kegiatan yang bertujuan membentuk nilai-nilai moral berorientasi politik bagi sivitas akademika (dalam hal ini lebih ditujukan kepada mahasiswa). Mahasiswa idealnya memiliki partisipasi politik yang tinggi karena warga negara yang berpendidikan tinggi dinilai lebih sadar dan aktif dalam berpartisipasi politik. Selain itu, mahasiswa sebagai penyandang gelar sebagai agent of change merupakan sosok kritis yang harus mengetahui tentang fenomena pelanggaran politik seperti money politics ini. Sebagai individu yang mendapatkan pendidikan politik di kampus, mahasiswa bertanggung jawab dalam perpolitikan negara (Pahlevi \& Amrurobbi, 2020).

Pendidikan politik merupakan awal munculnya revolusi sosial, di mana ideologi atau pemikiran politik tertentu dapat disebarluaskan dalam bentuk afektif dan psikomotor sehingga memberikan dampak positif terhadap lingkungan masyarakat. Fungsi perguruan tinggi adalah memberikan penguatan kepada peran organisasi kemahasiswaan untuk mengembangkan kesadaran mahasiswa akan hak dan kewajibannya sebagai warga negara (Ramdhani, 2019).

Tepatnya pada hari Rabu tanggal 9 Desember 2020 akan diadakan Pilkada (Pemilihan Kepala Daerah) Kota Dumai, Riau. Kepala daerah yang dipilih adalah Walikota dan Wakil Walikota Kota Dumai untuk periode 2020-2025. Pada Pilkada kali ini, terdapat empat pasangan calon Walikota dan Wakil Walikota yang mencalonkan diri, diantaranya: (1) Hendri Sandra Rizal Akbar; (2) Eko Suharjo - Syarifah; (3) Paisal - Amris; dan (4) Edi Sepen - Zainal Abidin. Lembaga Strategis Kajian Politik Dumai memprediksi bahwasanya yang akan menang adalah paslon ketiga yang akan meraih perolehan suara terbanyak di lima kecamatan. Paslon ini bersaing ketat dengan paslon nomor 2. Penelitian ini membahas tentang bagaimana penerapan pendidikan politik terhadap gerak politik uang pada Pilkada Dumai 2020 dari segi persepsi mahasiswa se-kota Dumai.

\section{Metode}

Penelitian ini adalah penelitian deskriptif kuantitatif. Penelitian deskriptif kuantitatif merupakan penelitian yang bertujuan menggambarkan keadaan atau status fenomena dan dianalisis. Penelitian ini menggunakan alat statistik dekriptif sehingga formulasi hipotesis tidak diperlukan (Suharsimi, 2006). Tujuan penelitian ini adalah untuk menggambarkan penerapan pendidikan politik terhadap fenomena politik uang pada saat akan dilaksanakannya Pemilu Walikota dan Wakil Walikota Kota Dumai tahun 2020 berdasarkan persepsi mahasiswa. Instrumen yang digunakan dalam penelitian adalah kuesioner (angket) Persepsi Mahasiswa terhadap Politik Uang pada Pemilihan Walikota dan Wakil Walikota Dumai tahun 2020 yang terdiri atas 10 pertanyaan menyangkut politik uang. Angket ini dikembangkan menggunakan skala Guttman, di mana hanya ada dua interval 'ya' dan 'tidak', 'pernah dan tidak pernah', 'tahu dan tidak tahu' karena peneliti ingin mendapatkan jawaban yang tegas dari responden (Sugiyono, 2007). Sebelum turun ke lapangan kuesioner ini telah diuji validitas dan 
reliabilitasnya. Uji coba dilakukan di STIE Tuah Tuah Negeri. Melalui pengujian validitas angket diperoleh hasil valid dengan rhitung kecil dari rtabel $(0,878)$ dan pengujian reliabilitas didapatkan hasil reliabel di mana hasil perhitungan rhitung sebesar 0,952 lebih besar dari rtabel 0,6 . Populasi penelitian adalah mahasiswa perguruan tinggi di kota Dumai yang terdaftar pada semester ganjil tahun ajaran 2020/2021. Responden penelitian berjumlah 760 orang yang didominasi oleh responden laki-laki dengan persentase $64,2 \%$ dan 35,8\% responden perempuan. Responden dipilih menggunakan teknik sampel insidental. Teknik ini dipilih karena peneliti memandang bahwa mahasiswa yang ditemui itu cocok dijadikan sebagai sampel (Sugiyono, 2007).

\section{Hasil dan Pembahasan}

Untuk mengetahui persepsi mahasiswa terhadap aktifitas politik uang yang akan berlangsung saat pemilihan Walikota dan Wakil Walikota Dumai pada tanggal 9 Desember 2020 nanti, berdasarkan angket yang telah diisi oleh responden, maka diperoleh hasil sebagai berikut:

Tabel 1. Persentasi Persepsi Mahasiswa tentang Politik Uang pada Pemilihan Walikota Dumai tahun 2020

\begin{tabular}{|c|c|c|c|c|}
\hline \multirow[t]{2}{*}{ No } & \multirow[t]{2}{*}{ Indikator } & \multicolumn{3}{|c|}{ Persentase (\%) } \\
\hline & & Ya & Tidak & Total \\
\hline 1 & Pengetahuan tentang politik uang & 74,7 & 25,3 & 100 \\
\hline 2 & $\begin{array}{l}\text { Pengetahuan tentang tujuan politik } \\
\text { uang }\end{array}$ & 71,7 & 28,3 & 100 \\
\hline 3 & $\begin{array}{l}\text { Pengetahuan dampak dari politik } \\
\text { uang terhadap Piemilihan } \\
\text { Walikota Dumai tahun } 2020\end{array}$ & 78,9 & 21,1 & 100 \\
\hline 4 & $\begin{array}{l}\text { Pengalaman menerima uang dari } \\
\text { pasangan calon atau tim sukses }\end{array}$ & 79,9 & 20,1 & 100 \\
\hline 5 & $\begin{array}{l}\text { Pengalaman menerima uang saat } \\
\text { pemilu sebelumnya }\end{array}$ & 73,6 & 26,4 & 100 \\
\hline 6 & $\begin{array}{l}\text { Perkiraan akan adanya politik uang } \\
\text { dalam Pemilihan Walikota Dumai } \\
\text { tahun } 2020\end{array}$ & 15 & 85 & 100 \\
\hline 7 & $\begin{array}{l}\text { Pernyataan sikap akan adanya } \\
\text { politik uang, uang diterima dan } \\
\text { paslon tersebut dipilih }\end{array}$ & 22,1 & 77,9 & 100 \\
\hline 8 & $\begin{array}{l}\text { Pernyataan sikap akan adanya } \\
\text { politik uang, uangnya diterima } \\
\text { tetapi paslon tidak dipilih }\end{array}$ & 28,6 & 71,4 & 100 \\
\hline
\end{tabular}

Dari data di atas diperoleh persentase dari setiap pertanyaan tentang persepsi mahasiswa terhadap politik uang dalam Pemilihan Walikota dan Wakil Walikota di kota Dumai tahun 2020. Pertama, dalam tabel 1 di atas digambarkan bahwa: Pertama, sejumlah 74,7\% mahasiswa di kota Dumai mengetahui tentang apa itu politik uang, sedangkan 25,3\% tidak mengetahui tentang politik uang. Kedua, sebesar $71,7 \%$ responden mengetahui tujuan dari politik uang dan sisanya $28,3 \%$ tidak tahu tujuan dari politik uang tersebut. Ketiga, 79,9\% responden memiliki pengalaman menerima uang dari tim sukses dan atau pasangan calon peserta Pemilihan Walikota dan wakil Walikota kota Dumai, dan hanya 20,1\% yang tidak pernah menerima uang. Keempat, 78,9\% responden sudah mengetahui dampak politik uang terhadap Pemilihan Walikota dan Wakil Walikota Dumai 2020, sementara 21,1\% responden yang tidak mengetahui. 
Kelima, sejumlah 73,6\% responden memiliki pengalaman menerima uang dari oknum pasangan calon saat pemilu sebelumnya dan $26,4 \%$ belum pernah menerima uang saat pemilu sebelum ini dilaksanakan. Keenam, pertanyaan tentang akan adanya politik uang saat Pemilihan Walikota dan Wakil Walikota dijawab dengan $85 \%$ responden menjawab tidak akan ada dan $15 \%$ dari responden menjawab politik uang akan terjadi. Ketujuh, pernyataan sikap responden saat menerima uang dan memilih pasangan calon yang dimaksud akan dilakukan oleh $22,1 \%$ responden, dan sebaliknya $77,9 \%$ responden bersikap tidak akan menerima uang dan tidak memilih pasangan calon tersebut. Terakhir, $71,4 \%$ responden bersikap tidak menerima uang yang diberikan dan tidak memilih pasangan calon tersebut dan sisanya $28,6 \%$ responden menerima uang dan tidak memilih calon pasangan yang memberikan uang tersebut.

\section{Pengetahuan Mahasiswa terhadap Politik Uang dalam Pemilihan Walikota dan Wakil Walikota Dumai Tahun 2020}

Pemilihan umum (Pemilu) merupakan salah satu perwujudan dari kedaulatan rakyat. Melalui asas Pemilu langsung umum, bebas, rahasia, jujur dan adil ini, jelaslah bahwa tujuan Pemilu adalah untuk melahirkan pemimpin yang adil, memiliki integritas tinggi, jujur dan mengedepankan kepentingan masyarakat. Oleh karena itu legitimasi kekuatan rakyat diserahkan sebagian kepada perwakilan yang duduk di parlemen. Begitu juga dalam pemilihan kepala daerah apakah itu gubernur dan wakil gubernur, walikota dan wakil walikota serta bupati dan wakil bupati yang merupakan sarana mengakomodasikan cita-cita masyarakat demi terciptanya kehidupan yang lebih baik.

Namun, pelanggaran dalam pemilu kepala daerah ini sering muncul di masa-masa pemilihan. Seringnya, alasan yang digunakan para pelaku yang notabene adalah para kontestan politik ini adalah karena pemilu memerlukan biaya yang besar dalam penyelenggaraannya sehingga mereka berlomba-lomba mendapatkan dukungan (suara rakyat) demi dapat menduduki kursi pemimpin di daerah masing-masing. Tak heran bila saat ini ditemukan pejabat publik yang korup untuk mengganti biaya politik yang cukup tinggi. Salah satu bentuk pelanggaran pemilu yang paling sering terjadi adalah adalah politik uang (money politics).

Politik uang telah diatur secara tegas dalam perundang-undangan sebagai salah satu pelanggaran dalam pemilihan kepala daerah dan bagi pelakunya telah ditetapkan sangsi yang berat pula. Sebagaimana diatur dalam Undang-Undang Nomor 10 tahun 2016 tentang Pemilihan Kepala daerah Pasal 187A ayat (1) yang berbunyi "Setiap orang dengan sengaja melakukan perbuatan melawan hukum menjanjikan uang atau materi lainnya sebagai imbalan kepada warga negara Indonesia baik secara langsung maupun tidak langsung untuk mempengaruhi pemilih agar tidak menggunakan hak pilih dengan cara tertentu sehingga suara menjadi tidak sah, memilih calon tertentu, atau tidak memilih calon tertentu sebagaimana dimaksud pasal 73 ayat (4) dipidana dengan pidana penjara paling singkat 36 (tiga puluh enam) bulan dan denda paling sedikit Rp. 200.000 .000 (dua ratus juta rupiah) dan paling banyak Rp. 1.000.000.000 (satu miliar rupiah)" (Nail, 2018). Hal senada juga diungkapkan oleh Aspinall dan Sukmajati dalam (Pahlevi \& Amrurobbi, 2020), di mana politik uang adalah salah satu usaha kontestan politik menyuap para pemilihnya dengan membagi-bagikan uang atau jasa secara cuma-cuma dengan maksud agar suara pemilih diberikan kepada kontestan ini.

Berdasarkan hasil sebaran angket di lapangan terhadap mahasiswa yang ada di perguruan tinggi di Kota Dumai, pengetahuan mahasiswa tentang politik uang dalam Pemilihan Walikota dan Wakil Walikota Dumai tahun 2020 sudah baik. Pengetahuan tersebut tidak hanya dari segi definisi tetapi juga dari segi tujuan dan dampak dari politik uang itu. Hal ini didukung oleh hasil angket yang menunjukkan bahwa $74,7 \%$ mahasiswa tersebut mengetahui tentang apa itu politik uang dan hanya 25,3\% tidak mengetahui tentang politik uang. Kemudian 71,7\% responden mengetahui tujuan dari politik uang dan sisanya $28,3 \%$ tidak tahu tujuan dari politik uang tersebut. Begitu juga dampak politik uang yang sudah diketahui oleh 78,90\% mahasiswa. 


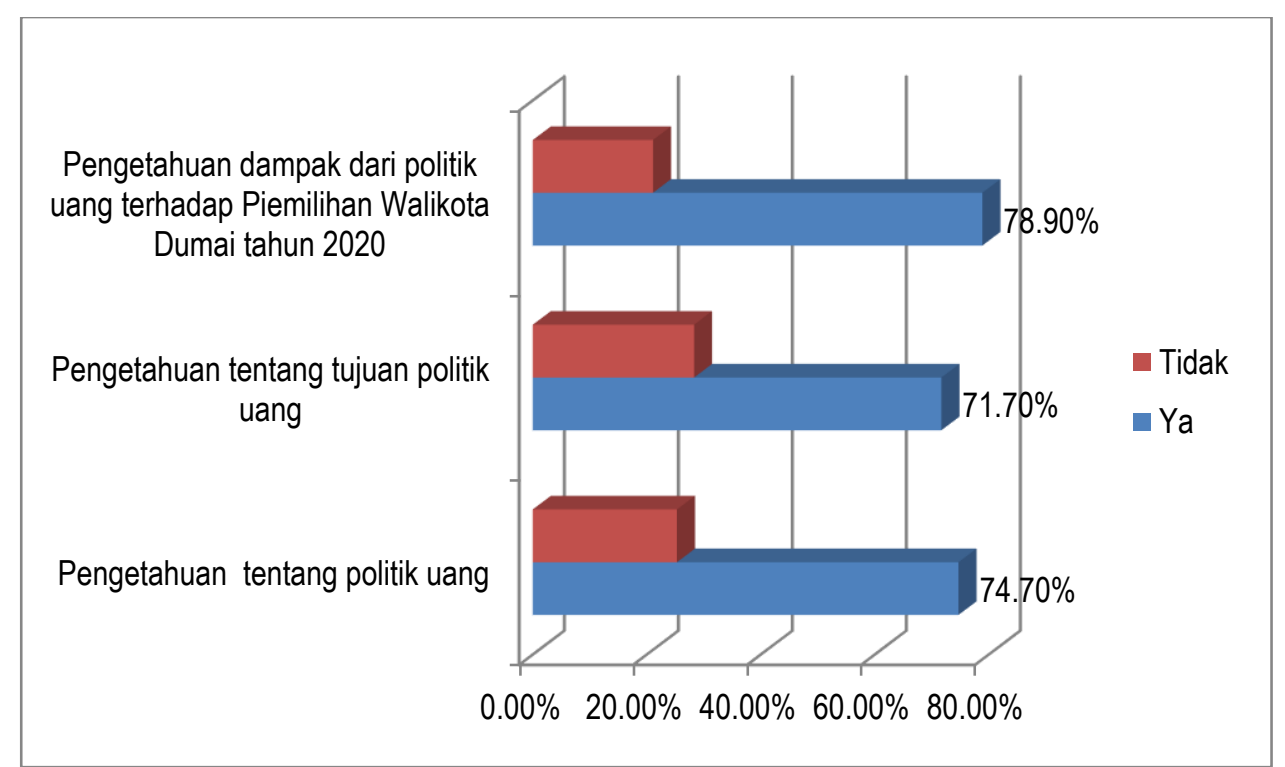

Gambar 1. Persentase Pengetahuan Mahasiswa tentang Politik

\section{Realisasi Pendidikan Politik Yang Diperoleh Mahasiswa Dengan Praktiknya Dalam Pemilihan Walikota dan Wakil Walikota Dumai Tahun 2020}

Pendidikan politik merupakan awal munculnya revolusi sosial, di mana ideologi atau pemikiran politik tertentu dapat disebarluaskan dalam bentuk afektif dan psikomotor sehingga memberikan dampak positif terhadap lingkungan masyarakat. Fungsi perguruan tinggi adalah memberikan penguatan kepada peran organisasi kemahasiswaan untuk mengembangkan kesadaran mahasiswa akan hak dan kewajibannya sebagai warga negara (Ramdhani, 2019).

Salah satu bentuk pelaksanaan pendidikan politik ini adalah proses demokrasi dalam penentuan hak setiap warga negara. Hal ini tertuang dalam pasal 34 Undang-Undang Nomor 39 Tahun 1999 tentang HAM yang berbunyi: "Setiap warga negara berhak dipilih dan memilih dalam pemilu, berdasarkan hak melalui pemungutan suara yang langsung, umum, bebas dan rahasia, jujur, adil sesuai ketentuan perundang-undangan”. Bentuk tercapainya proses tujuan pendidikan politik dalam pasal ini adalah kesadaran akan hak dan kewajiban serta mempunyai tanggungjawab yang dilandasi oleh nilai-nilai yang berlaku dalam kehidupan berbangsa dan bernegara. Hal ini tidak dapat dilihat secara langsung karena dibutuhkan waktu yang cukup lama untuk melihat perubahan sikap dan perilaku seseorang ke arah yang lebih baik (RAHMADI, 2016).

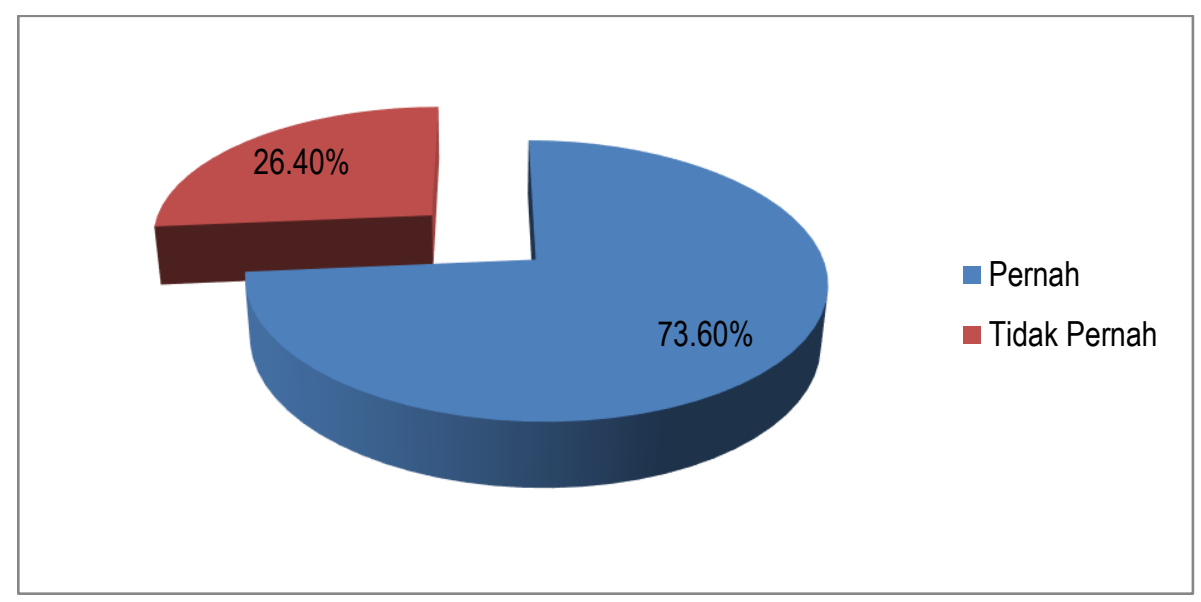

Gambar 2. Persentase Responden Yang Pernah Menerima Uang Dari Timses Atau Paslon 
Proses pendidikan politik dalam diri mahasiswa di perguruan tinggi se-kota Dumai telah berlangsung dengan baik. Hal ini seperti digambarkan pada Chart 2 di atas. Chart ini mendeskripsikan bahwa Pemilu sebelum tahun 2020, sebagian besar mahasiswa pernah menerima uang dari tim sukses dan atau pasangan calon dengan persentase $73,60 \%$. Sebaliknya, mahasiswa yang tidak pernah menerima presentasenya lebih kecil yaitu $26,40 \%$ saja.
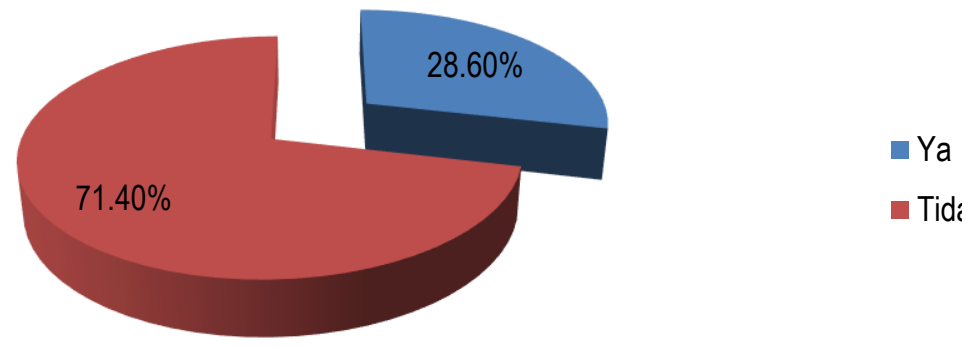

- Tidak

Gambar 3. Persentase Pernyataan Sikap Menolak Politik Uang Dengan Memanfaatkan Uang Yang Diberikan

Sebagai tambahan, berdasarkan deskripsi pada Chart 3 di atas, meskipun responden pernah menerima uang dari tim sukses atau pasangan calon dalam pemilihan sebelumnya, namun sikap untuk menolak politik uang ditunjukkan dari hasil angket. Para responden berani menerima uang yang diberikan karena membutuhkan uang tersebut dengan persentase sebesar $71,40 \%$ tetapi berani juga menolak untuk memilih pasangan calon yang memberikannya. Sementara itu, bagi responden yang menerima uang dan memilih pasangan calon tersebut presentasenya $28,60 \%$. Chart 3 menunjukkan realisasi bahwasanya mahasiswa telah mengalami proses pembelajaran politik bahwasanya politik uang tersebut tidak baik dalam proses demokrasi Indonesia.

Hal ini sesuai dengan pendapat (Wahyu, 2019) yang mendefinisikan politik uang sebagai kanker dalam demokrasi Indonesia. Ia mengibaratkan politik uang ini seperti sebuah pertumbuhan sel kanker dalam tubuh demokrasi kita yang menggerogoti nilai kejujuran dan keadilan sehingga lama kelamaan dapat merusak moralitas politik. Politik uang ini berawal dari ditetapkannya partisipasi massa (masyarakat) dalam pemilihan langsung kepala daerah pada tahun 2005. Adanya pergeseran politik uang dari sesama anggota legislatif selaku pemilih di parlemen menjadi masyarakat sebagai pemilih langsung yang memiliki suara menjadi penyebabnya. Tak hanya pemilih yang telah bergeser, bentuk praktek politik uang in pun telah berkembang. Tak hanya menyogok menggunakan uang saja tetapi sudah dalam bentuk pemberian jasa seperti pengobatan gratis, asuransi, pemberian proyek, bantuan pembangunan sarana umum seperti jalan atau tempat ibadah bahkan juga telah merambah ke dalam bentuk kegiatan sosial dan berbagai macam bentuk perlombaan.

\section{Kesimpulan}

Pemilihan umum (Pemilu) merupakan salah satu perwujudan dari kedaulatan rakyat. Melalui asas Pemilu langsung umum, bebas, rahasia, jujur dan adil ini, jelaslah bahwa tujuan Pemilu adalah untuk melahirkan pemimpin yang adil, memiliki integritas tinggi, jujur dan mengedepankan kepentingan masyarakat. Oleh karena itu legitimasi kekuatan rakyat diserahkan sebagian kepada perwakilan yang duduk di parlemen. Begitu juga dalam pemilihan kepala daerah apakah itu gubernur dan wakil gubernur, walikota dan wakil walikota serta bupati dan wakil bupati yang merupakan sarana mengakomodasikan cita-cita masyarakat demi terciptanya kehidupan yang lebih baik. 
Politik uang dalam Pemilihan Walikota dan Wakil Walikota Dumati tahun 2020 ini merujuk pada tindakan menyogok para kontestan pemilu untuk masyarakat dengan memberikan secara percuma pemberian seperti uang dan jasa dengan tujuan agar suara pemilih ditujukan untuk kontestan tersebut agar memenangkan pemilihan. Hal ini jelas bertentangan dengan perundang-undangan yang berlaku dan untuk para pelakunya telah disiapkan sanksi yang tegas.

Dalam kaitannya dengan pendidikan politik dimana pendidikan ini meliputi aspek kesadaran mahasiswa terhadap hak dan kewajibannya di bidang politik. Salah satu yang menjadi hak mereka adalah memilih dan dipilih dalam pemilu baik di tingkat nasional maupun daerah melalui pemungutan suara yang berasaskan luber dan jurdil. Pengetahuan mengenai politik uang yang dilarang dalam pemilu menjadi sebuah kewajiban bagi mahasiswa untuk dapat tegas menolaknya. Hal ini dapat terlihat dari adanya perubahan sikap dan perilaku mahasiswa di Kota Dumai dalam menghapapi Pemilihan Walikota dan Wakil Walikota tahun 2020 dari yang biasanya menerima karena alasan ekonomi dan kebutuhan menjadi perilaku penolakan disebabkan alasan pengetahuan dan kesadaran akan bahaya politik uang terhadap demokrasi dan prosesnya. Kesimpulan harus menjawab permasalahan penelitian dan temuan dari penelitian yang dilakukan. Dapat juga memberikan saran atau rekomendasi untuk proyek riset berikutnya.

\section{Daftar Pustaka}

Firdaus, A. (2020). Money Politics dalam Pemilihan Umum oleh Badan Pengawasan Pemilihan Umum: Pengawasan Tindak Pemilu. Justiqa, 02(01), 61-69.

Nail, M. H. (2018). Kualifikasi Politik Uang dan Strategi Hukum dan Kultural atas Pencegahan Politik Uang dalam Pemilihan Umum. 5(2), 245-261.

Pahlevi, M. E. T. P., \& Amrurobbi, A. A. (2020). Pendidikan Politik dalam Pencegahan Politik Uang Melalui Gerakan Masyarakat Desa. Jurnal Antikorupsi Integritas, 6(1), 141-152.

RAHMADI, D. S. (2016). Peran Elit Politik Lokal dalam Pendidikan Politik Mahasiswa di Kabupaten Lombok Timur. SOCIA: Jurnal Ilmu-Ilmu Sosial, 13(1). https://doi.org/10.21831/socia.v13i1.9901

Ramdhani, H. (2019). Studi Komparatif Kurikulum Pendidikan Politik di Perguruan Tinggi. Prosiding Senas POLHI Ke-2 Tahun 2019, 79-85.

Robi Cahyadi Kurniawan, D. H. (2019). Strategi Sosial Pencegahan Politik Uang di Indonesia. Jurnal Integritas KPK 2019, 5(1), 29-41.

Sugiyono. (2007). Statistik untuk Penelitian (E. Mulyatiningsih (ed.)). Alfabeta Bandung.

Tri Wulandari, N. A., \& Dayati, U. (2020). Hubungan Pengetahuan Kewarganegaraan dengan Partisipasi Politik Mahasiswa. Jurnal Ilmiah Pendidikan Pancasila Dan Kewarganegaraan, 4(2), 361. https://doi.org/10.17977/um019v4i2p361-367

Wahyu, Y. (2019). Setengah Hati Berantas Politik Uang. In D. S. Kartini (Ed.), Serial Evaluasi Penyelenggaraan Pemilu Serentak 2019: Perihal Penyelenggaraan Kampanye (Pertama, pp. 111-138). BAWASLU : Badan Pengawas Pemilu. www.bawaslu.go.id 